\title{
Pharmacognostic study of Walnut (Juglans regia L.) endocarp from Azad Jammu Kashmir (AJK)
}

\author{
Sumbul Qadar ${ }^{1}$, Maqsood Anwar ${ }^{1}$, Shah Khalid ${ }^{1}$, Naila Azam² and Izhar \\ Ahmad $^{1 *}$ \\ 1. Department of Botany, Islamia College Peshawar-Pakistan \\ 2. Centre of Plant Biodiversity, University of Peshawar-Pakistan \\ *Corresponding author's email: izhar.ahmad@icp.edu.pk \\ Citation \\ Sumbul Qadar, Maqsood Anwar, Shah Khalid, Naila Azam and Izhar Ahmad. Pharmacognostic study of Walnut \\ (Juglans regia L.) endocarp from Azad Jammu Kashmir (AJK). Pure and Applied Biology. Vol. 10, Issue 1, pp97- \\ 104. http://dx.doi.org/10.19045/bspab.2021.100011
}

Received: 09/01/2020 Revised: 22/03/2020

Accepted: $27 / 03 / 2020$

Online First: $18 / 09 / 2020$

\section{Abstract}

The present study explains antimicrobial activity and acute toxicity of walnut (Juglans regia L.) endocarp from Azad Jammu Kashmir (AJK). The walnut endocarp extract tested against fungal species i.e. Aspergillus niger and Penicillium notatum and bacterial species i.e. Staphylococcus aureus and Escherichia coli. Aspergillus niger and Penicillium notatum. at 10, 100 and 1000 $\mu \mathrm{g} / \mathrm{ml}$ concentrations showed Diameter Inhibition Zone (DIZ). Diameter Inhibition Zone (DIZ) was maximum against Aspergillus niger in all concentrations as compared to Penicillium notatum. Similarly, Staphylococcus aureus showed higher Diameter Inhibition Zone (DIZ) at 10, 100 and $1000 \mu \mathrm{g} / \mathrm{ml}$ concentration respectively as compared to Escherichia coli Diameter Inhibition Zone (DIZ) at the same concentrations. Acute toxicity of walnut endocarp extract showed the significant result at $100 \mathrm{mg} / \mathrm{kg}, 200 \mathrm{mg} / \mathrm{kg}$ and $400 \mathrm{mg} / \mathrm{kg}$ concentrations with $0 \%$ mortality. It was concluded that walnut endocarp may be important source of antimicrobial activity and may be used in pharmacognosy.

Keywords: Acute toxicity; AJK; Antimicrobial activity; Pharmacognocy; Walnut

\section{Introduction}

Pharmacognosy is the systematic study of properties that is structural, chemical and biological effects of crude drugs are studied, method of cultivation, drying, collection, preservation and preparation. Mostly the crude drugs are obtained from different parts of plant or from a whole plant [1]. Therapeutic agents are isolated from different medicinal plant by different way that is modern, Unani, Chinese and traditional system of medicine. On the basis of chemical analysis, modern systems of medicine have negative reaction and traditional system of medicine have no side effect and produce good actions [2]. Medicinal plants comprise some bioactive organic complexes that is carbohydrates, tannins, flavonoids, alkaloids, steroids and terpenoids which offer precise biological action on the human body. The chemical constituents of plant are helpful because such information was important for the manufacture of complex chemical 
constituents [3]. Different parts of the plants such as flowers, fruits, leaves, seeds, roots, endocarp and bark are bases for the origin of secondary metabolites. The plants that contains phytochemicals have constantly played a vital role in medicine [4]. Medicinal plants are used by hakims as $80 \%$ of the population living in the villages that are totally dependent on the traditional system of medicines [5].

Juglans regia L. commonly known as "walnut plant" is the wide spread nut tree in the biosphere belongs to family Juglandaceae. It is a distinctive plant having medicinal uses. All parts of walnut can be useful for humans. Previously the Ancient, Greeks and Romans describe and studied the walnut and Theophrastus, "the father of botany" was one of the first to designate walnut [6]. The production of walnut is increase worldwide. The pairs of walnut have been rotated and played with in the palm of the hand to stimulate the circulation blood and as a status symbol in Chinese culture [7]. J. regia L. are used for the preparation of Batch flower remedies, a kind of alternative medicine promoted for its effect on health [8]. Juglone is a chemical release from $J$. regia L. has toxic properties and it is toxic to different plant species at diverse levels. Juglone is occur in significant quantities in all parts of walnut and in endocarp is very little or absent [9]. They recognized the juglone had cytotoxic potential against tumor cells in human [10]. All parts of J. regia L. have vitamins i.e. C, A, E, and group B, organic acids, minerals, and tannins are also present. When fruit is unripe it consist of vitamin $\mathrm{C}$ about 3 to $5 \%$. The commencement of endocarp solidification vitamin $\mathrm{C}$ was found in large quantity [11]. $J$. regia L. has nutrient properties carbohydrates, vitamins, minerals, fats and proteins. It is an important basis of flavonoids, steroids, pectic compounds and phenolic acids [12].

\section{Materials and Methods}

Plant collection and powder preparation

The walnut fruits were collected from Azad Jammu Kashmir (AJK) in clean polythene bags in March 2016. The collected sample was brought in to the laboratory, Department of Botany Islamia College Peshawar. The fruits were broken and the endocarp was separated. The endocarps were grinded with the help of electric grinder in the form of powder. The powder was closed in the air tight bottle and protected from the dust and moisture. This powder was further used for pharmacognostic studies (Fig. 1).

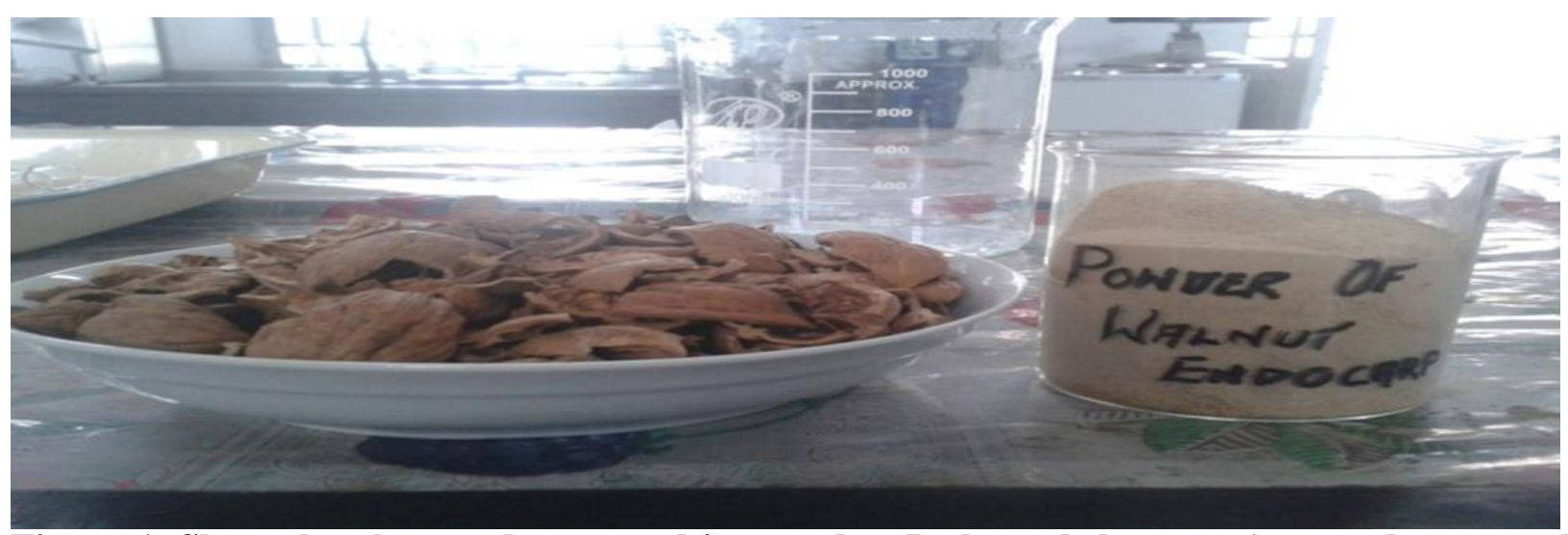

Figure 1. Showed walnut endocarp and its powder. It showed the J. regia L. endocarp and its powder form after grinding, it indicate the p physical character (brown in colour, rough texture, no smell and tasteless). 


\section{Preparation of crude extract}

$200 \mathrm{~g}$ powder of walnut endocarp was taken in the clean beaker and add 500ml ethanol. The beaker was covered with aluminum foil and protect from moisture, dust particle and other materials. Left it for 15 days, every day shaking and stirring would be done for few hours. After 15 days solution was filtered by using cotton material, then it was again filtered by Whattman filter paper. The mixture was transferred in to rotary evaporator to evaporate the ethanol from extract. At the end, concentration was obtained that is crude ethanolic extract of walnut endocarp. The crude extract was collected in a close voile, and would be used for performing further activities.

\section{Antifungal activity}

The agar well diffusion assay method [13] was used to determine the activity of walnut endocarp extract. The Saboured Dextrose (SD) media was cast off for antifungal activity. Aspergillus niger and Penicillium notatum was used to studied antifungal activity at various concentrations.

\section{Media preparation}

For preparation of Saboured Dextrose Medium (SDM), 40g of Dextrose and 14$15 \mathrm{~g}$ of Agar was dissolved in $1000 \mathrm{ml}$ distilled water and $10 \mathrm{~g}$ of peptones was included in it and autoclaved at $121^{\circ} \mathrm{C}$ temperature for 20 minutes at $15 \mathrm{psi}$ pressure.

\section{Inoculation and antifungal activity}

Fungal lawns were prepared with the help of cotton swabs by dextrose broth. Well was formed in petri dishes by metallic borer. Various concentrations 10, 100 and $1000 \mu \mathrm{g} / \mathrm{ml}$ of walnut endocarp extract was passed by micropipette in each well of petri dish. Fungicide (Amoxicillin) was taken and added in the well, served as a positive control and DMSO (Dimethyl sulfoxide) was castoff as negative control. Petri dishes were transferred in to incubator at $28^{\circ} \mathrm{C}$ for 5 to 6 days. Diameter of zone of inhibition
(DIZ) was forced round the well in each petri dish after incubation period. This zone of inhibition showed that the extract have the potential of antifungal activity [14]. After 6 to 7 days, Diameter of zone of inhibition (DIZ) was measure using scale. Percentage inhibition was designed by formula;

$\%$ inhibition $=($ Zone of inhibition of sample $) \times 100$

(Zone of inhibition of standard)

Antibacterial activity

The agar well diffusion method was used for purpose of antibacterial activity [15]. Two bacterial strains i.e. Staphylococcus aureus and Escherichia coli were used for antimicrobial activity.

Media preparation, inoculation and autoclaving

For this $2 \mathrm{~g}$ of agar, $0.5 \mathrm{~g}$ of Peptone and $0.3 \mathrm{~g}$ Yeast extract was dissolved in $100 \mathrm{ml}$ distilled water and then autoclaved. The Nutrient broth medium (NBM) was made as the Nutrient agar medium (NAM) except agar. Nutrient broth medium was poured in to each test tube $(10 \mathrm{ml})$. Put the test tubes in a beaker and Nutrient agar medium in a flask which was covered with cotton and aluminum foil. Petri dishes was covered with newspaper and placed in autoclave along with nutrient agar and nutrient broth media at $121^{\circ} \mathrm{C}$ temperature for 20 minutes at 15 psi pressure for pasteurization. After autoclaving Nutrient agar medium (NAM) and Nutrient broth medium (NBM) was placed in Laminar Flow Hood (LFH) while petri dishes were transferred in oven at $189^{\circ}$ $\mathrm{C}$ for oven at aridness. Petri dishes was also transferred to Laminar Flow Hood (LFH) after dryness. Nutrient agar medium was poured into petri dishes and leave these petri dishes for few minutes to solidify. Petri dishes was wrapped with sticky tape. The petri dishes were labeled and reserved in incubator for 24 hours.

\section{Inoculation and antibacterial activity}

For antibacterial activity small slice of bacterial strain was transferred by the loop 
that was sterilized by heating into the test tubes having nutrient broth medium was present in it. Test tubes were covered with cotton and aluminum foil. The test tubes were given named. Then the test tubes were placed in a beaker with great care and were transferred to incubator at $37^{\circ} \mathrm{C}$ for 24 hours. Next day test tubes that contained distilled water and cotton swabs were covered with the foil were put in autoclaved for sterilization. After this test tubes, petri dishes having culture of bacteria and cotton swabs were taken and placed in Laminar Flow Hood (LFH). Now test tubes were taken that contained bacteria and nutrient broth. By the help of micropipette a portion of it was relocated in to the test tube have distilled water. Uniform lawn of the bacteria was formed by the cotton swabs on the nutrient agar petri dishes and permitted for 5 minutes. Using cork borer wells were made on the petri dishes that contained nutrient agar media.

Stock solution was formed by $5 \mathrm{mg}$ of the walnut endocarp extract that was dissolved in the $3 \mathrm{~mL}$ DMSO (Dimethyl sulfoxide). Prepared 10, 100 and $1000 \mu \mathrm{g} / \mathrm{ml}$ concentrations. They were be added to every well and was labeled by the help of marker. Amoxicillin was used as positive control and DMSO (Dimethyl sulfoxide) was for the negative control. The petri dishes were covered with sticky tape and were placed in the incubator for one day at $37^{\circ} \mathrm{C}$ for the purpose of zone of diameter of inhibition. Zone of inhibition was measured on next day by the use of the ruler. \% inhibition was calculated by the formula;

$\%$ inhibition $=($ Zone of inhibition of sample $) \times 100$

(Zone of inhibition of standard)

\section{Acute toxicity}

The study of acute toxicity was performed on ethanolic extract of $J$. regia L. by using albino mice having weight of $25 \mathrm{~kg}$ to $30 \mathrm{~kg}$. The mice were arbitrarily dispersed in to 4 groups each with 6 mice. The mice were get used to research laboratory environment before the beginning of test. The mice were dispossessed from food full night, control group was treated with normal saline and the residual 2 to 4 groups were treated with $100 \mathrm{mg} / \mathrm{kg}, 200 \mathrm{mg} / \mathrm{kg}$ and $400 \mathrm{mg} / \mathrm{kg}$ body weight respectively of the walnut endocarp extract. The mice were perceived constantly for the first 4 hours and then for the succeeding 24 hours [16]. Mice were kept fast for 24 hours before the experiment was performed and divided into 6 groups. Group one was inoculated with normal saline $(10 \mathrm{ml} / \mathrm{kg})$ as a negative control, group two with standard $(10 \mathrm{mg} / \mathrm{kg})$ as positive control, group three with $1 \%$ acetic acid for stimulate pain (writhing) while group 4 to 6 were injected with 100, 200 and $400 \mathrm{mg} / \mathrm{kg}$ of Walnut endocarp. After 20 minutes, $1 \%$ acetic acid was inserted to every mice. After 5 minutes, mice were separately observed to count the number of writhing (painful muscle contraction) or elongating reaction for 20 minutes. The mean number of writhing and the $\%$ inhibition were designed and the groups were related with the control group;

Percent writhes inhibition $=\underline{100-A-B} \times 100$

$$
\text { A }
$$

Where;

$A=$ Average number of writhes of the positive control

$\mathrm{B}=$ Average number of writhes of the test group

Results and Discussion

Following biological activities were performed for the determination of pharmacological potential on the ethanolic extract of $J$. regia L. endocarp.

\section{Antifungal activity}

In antifungal activity the ethanolic extract of J. regia L. was tested on different fungi Aspergillus niger and Penicillium notatum. Dissimilar dose of concentrations that is 10 , 100 and $1000 \mu \mathrm{g} / \mathrm{ml}$ inhibit the growth with different zone of inhibition. In Walnut endocarp dose of 10, 100 and $1000 \mu \mathrm{g} / \mathrm{ml}$ concentrations displayed the zone of 
inhibition i.e, $7.00 \pm 0.75,11.83 \pm 0.76$ and $15.67 \pm 1.04$ against Aspergillus niger. Amongst this walnut endocarp has higher Diameter of zone of inhibition (DIZ) at 1000 $\mu \mathrm{g} / \mathrm{ml}$ concentration (Table 1; Fig. 2). Results were fairly related with the results detected by [17], who worked on antifungal activity of Punica granatum shell and determined maximum activity against Aspergillus niger i.e. $22 \mathrm{~mm}$. The outcomes are also similar with [18], that showed highest antifungal activity of Aspergillus niger against shell of pomegranate i.e. 16, 12 and $10 \mathrm{~mm}$ respectively. Dose of 10,100 and $1000 \mu \mathrm{g} / \mathrm{ml}$ concentration of Walnut endocarp extract have exhibited the zone of inhibition $5.90 \pm 0.79, \quad 9.83 \pm 1.04$ and $12.67 \pm 0.76$ respectively against Penicillium notatum. Highest Diameter of zone of inhibition (DIZ) has found at $1000 \mu \mathrm{g} / \mathrm{ml}$ concentration. Our results also showed overall higher diameter of inhibition zone at 10, 100 and $1000 \mu \mathrm{g} / \mathrm{ml}$ concentration against Aspergillus niger as compare to Penicillium notatum at each concentration.

\section{Antibacterial activity}

The antibacterial activity of walnut endocarp extract against different bacteria Escherichia coli and Staphylococcus aureus. The results confirmed that Staphylococcus aureus inhibits highest Diameter of zone of inhibition (DIZ) 12.66 \pm 0.76 against walnut endocarp at $1000 \mu \mathrm{g} / \mathrm{ml}$ concentration and lower diameter of inhibition zone $9.16 \pm 0.76$, $6.00 \pm 1.0$ at $100 \mu \mathrm{g} / \mathrm{ml}$ and $10 \mu \mathrm{g} / \mathrm{ml}$ concentration respectively. Escherichia coli prevent minimum Diameter of zone of inhibition (DIZ) as $4.83 \pm 0.38$ at 10 concentrations, $\quad 7.0 \pm 0.50$ at 100 and maximum Diameter of zone of inhibition (DIZ) $9.5 \pm 0.50$ at $1000 \mu \mathrm{g} / \mathrm{ml}$ concentration. Our results also showed overall higher diameter of inhibition zone at 10, 100 and $1000 \mu \mathrm{g} / \mathrm{ml}$ concentration against Staphylococcus aureus as compare to Escherichia coli at each concentration (Table 2; Fig. 3).

Staphylococcus aureus showed the maximum diameter of inhibition zone $34.0 \pm 1.7 \mathrm{~mm}$ in the shell of pomegranate [19]. Present findings are similar with [20] who described that maximum antibacterial influence was noted on Staphylococcus aureus and showed higher diameter of inhibition zone that is $25 \mathrm{~mm}$. The results given in the table were also related to the consequences detected higher Diameter of zone of inhibition (DIZ) 19, 14 and 10mm against Staphylococcus aureus respectively at dissimilar absorptions of shell of pomegranate [18]. Extract of barks, fruits and green rinds of walnut from various area showed antibacterial activity against bacterial strains i.e. Staphylococcus aureus, Pseudomonas spp. and Escherichia coli, using agar streak method [21, 22].

Table 1. Diameter of inhibition zone (DIZ) of pathogenic fungi against J. regia L. endocarp at three different concentrations.

\begin{tabular}{|c|c|c|c|}
\hline Fungi & $\begin{array}{c}10 \text { Concentration } \\
(\boldsymbol{\mu g} / \mathbf{m l})\end{array}$ & $\begin{array}{c}100 \text { Concentration } \\
(\boldsymbol{\mu g} / \mathbf{m l})\end{array}$ & $\begin{array}{c}1000 \text { Concentration } \\
(\boldsymbol{\mu g} / \mathbf{m l})\end{array}$ \\
\hline Penicillium spp. & $5.90 \pm 0.79$ & $9.83 \pm 1.04$ & $12.67 \pm 0.76$ \\
\hline Aspergillus niger & $7.00 \pm 0.75$ & $11.83 \pm 0.76$ & $15.67 \pm 1.04$ \\
\hline
\end{tabular}




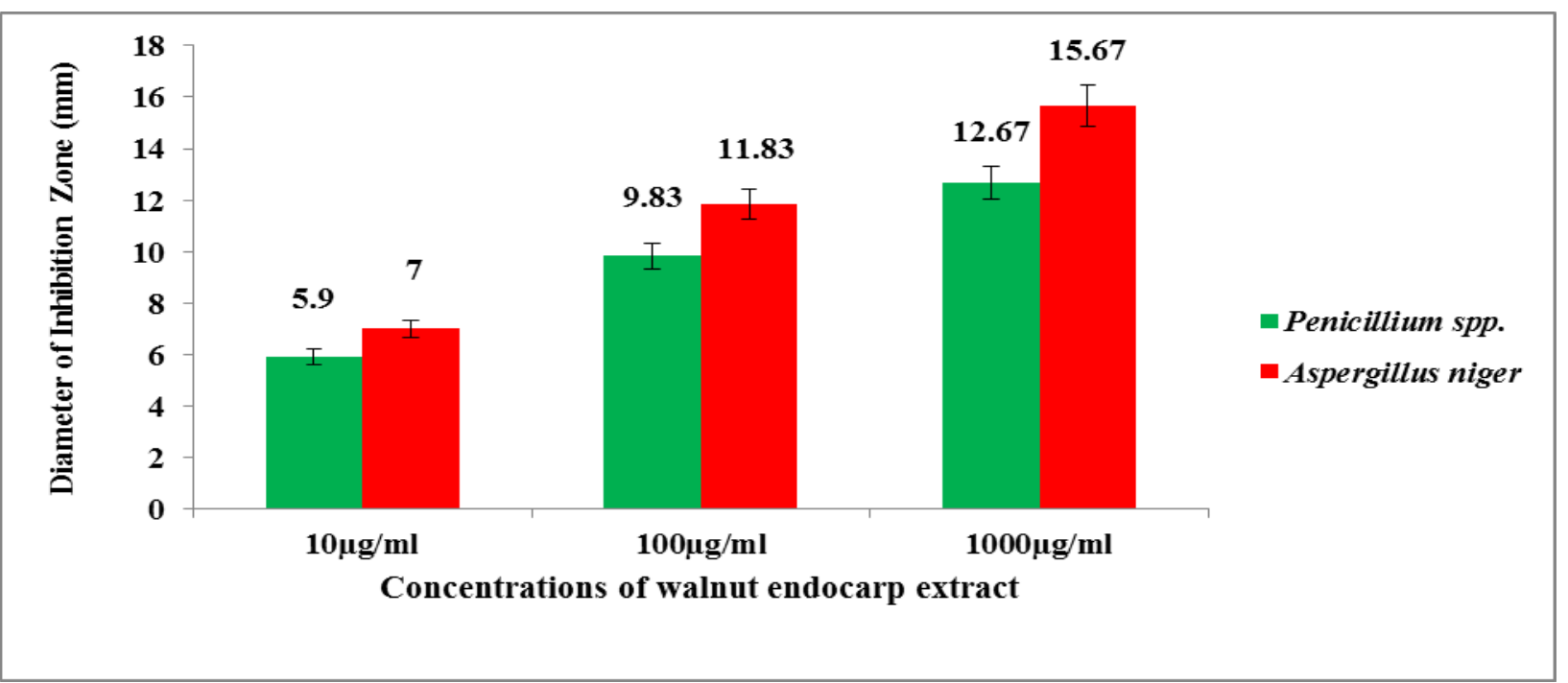

Figure 2. Antifungal activity of ethanolic extract of walnut endocarp. It shows the DIZ is greater in Aspergillus niger as compare to Penicillium notatum. at 10,100 and1000 $\mu \mathrm{g} / \mathrm{ml}$ concentration

Table 2. Diameter of inhibition zone (DIZ) of Bacteria against $J$ regia L. endocarp at three different concentrations.

\begin{tabular}{|c|c|c|c|}
\hline Bacteria & $\begin{array}{c}10 \text { Concentration } \\
(\boldsymbol{\mu g} / \mathbf{m l})\end{array}$ & $\begin{array}{c}100 \text { Concentration } \\
(\boldsymbol{\mu g} / \mathbf{m l})\end{array}$ & $\begin{array}{c}1000 \text { Concentration } \\
(\boldsymbol{\mu g} / \mathbf{m l})\end{array}$ \\
\hline Staphylococcus aureus & $6.00 \pm 1.0$ & $9.16 \pm 0.76$ & $12.66 \pm 0.76$ \\
\hline E. coli & $4.83 \pm 0.38$ & $7.0 \pm 0.50$ & $9.5 \pm 0.50$ \\
\hline
\end{tabular}

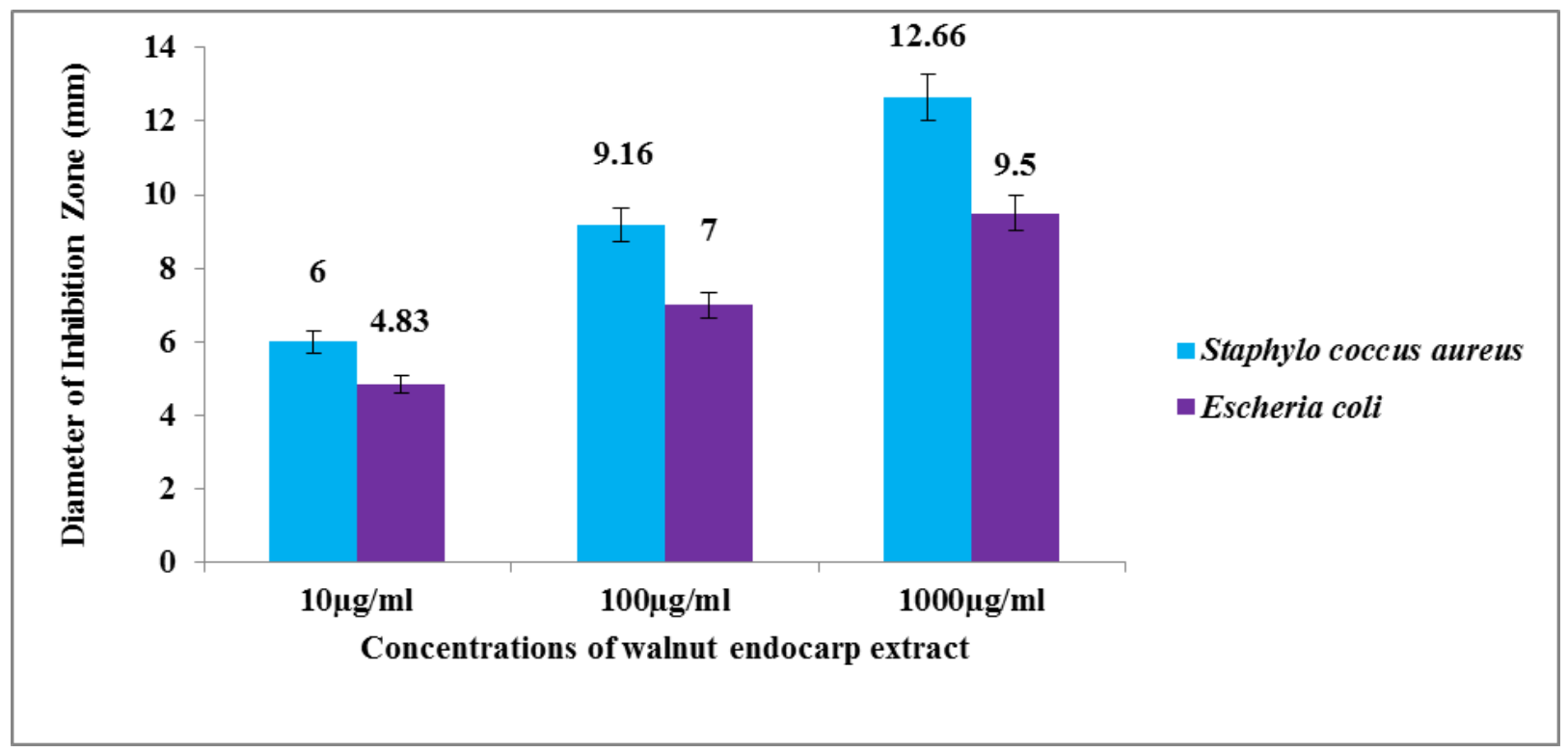

Figure 3. Antibacterial activity of ethanolic extract of walnut endocarp. It shows that the Staphylococcus aureus have high DIZ at 10,100 and $1000 \mu \mathrm{g} / \mathrm{ml}$ as compare to the $E$ coli 


\section{Acute toxicity}

The present study was conducted using mice for acute toxicity of $J$. regia $\mathrm{L}$. endocarp ethanolic extract following the method [16]. The evaluation of toxicity is essential, as plant extract was used for the beneficial of human beings for effective and safe dose management [23]. Therefore, our result showed that doses of the J. regia L. endocarp extract is safe for living organisms.Endocarp is not use as a crope residue but have a large amount of lignin content and energy which is used for the bio-products as compare to other biomass resourses [24]. The methanolic extract of walnut endocarp use as a natural additive constituent in food and pharmacological industries [25].

\section{Conclusion}

The aim of this research was to investigate the medicinal value of endocarp of $J$. regia L. and its possible uses, as endocarp of walnut is wasted mostly by the human being. So this study was conducted to determine the medicinal importance in endocarp of $J$. regia L. Pharmacognostic studies help us in the detection of adulteration and identification of crude extract which is used against bacterial, fungal diseases and acute toxicity in J. regia $\mathrm{L}$ were analyzed. We tried to explore the endocarp for pharmacological value and to commercialize on industrial scale.

\section{Authors' contributions}

Conceived and designed the experiments: $\mathrm{N}$ Azam, Performed the experiments: S Qadar, Analyzed the data: S Qadar, Contributed materials/analysis/tools: I Ahmad \& S Khalid, Wrote the paper: M Anwar.

\section{References}

1. Chauhan S, Singh L \& Sharma AK (2013). Pharmacognostic study and establishment of parameters of leaves, root and bark of (Ficus retusa L.) J Med Plant Stud 1(1): 38-46.
2. Arote SR \& Yeole PG (2010). (Pongamia pinnata L.): A comprehensive review. J Pharm Tech Res 2(4): 22832290.

3. Yadav RNS \& Agarwala M (2011). Phytochemical analysis of some medicinal plants. J Phytol 3(12): 10-14.

4. Aggarwal BB, Kumar A \& Bharti AC (2003). Anticancer potential of curcumin: preclinical and clinical studies. Anticancer Res 23: 363-398.

5. Soomro R, Qureshi RA, Mahmood MT, Khan MA \& Makka GA (1997). Ethobotanical uses of (Adhatoda vesica) in chest diseases. Hamdard Medicus 40: 91-93.

6. Derzhavina NA (2000). Healing walnut. Respeks, St. Petersburg, 64 pp. (in Russian). Ji Y, Qua Z \& Zoua X (2009). Juglone-induced apoptosis in human gastric cancer SGC-7901 cells via the mitochondrial pathway. Exp Toxicol Pathol 63(1-2): 69-78.

7. Jason S \& Lee JL (2012). Statusconscious investors shell out on great walnuts of China.

8. Vohra DS (2005). Bach flower remedies, a comprehensive study. B Jain publishers (P) Ltd.

9. Cosmulescu S, Trandafir I, Achim G \& Baciu A (2011). Juglone content in leaf and green husk of five walnut (Juglans regia L.) cultivars. Notulae Botanicae Horti Agrobotanicil 39: 237-240.

10. Kamei H, Koide T, Kojima T, Hashimoto Y \& Hasegawa M (1998). Inhibition of cell growth in culture by quinones. Cancer Biother Radiopharm 13: $185-8$.

11. Pilipenko TV \& Orlova OU (2009). Development of formulations of foods using raw walnut milky-wax ripeness. In Baranenko AV (ed.): Collection of materials 3rd International Scientific and Technical Conference Low-Temperature 
and Food Technologies in XXI century. SPbGUNiPTS St. Petersburg 290-291.

12. Muradoglu FH, Oguz I, Yildiz K \& Yilmaz H (2010). Some chemical composition of walnut (Juglans regia L.) selection from eastern Turkey. Afr J Agri Res 5: 2379-2385.

13. Rout Y, Behera S, Ojha A \& Nayak PL (2012). Green synthesis of silver nanoparticals using (Ocimum sanctum) (Tulashi) and study of their antibacterial and antifungal activities. Synergy Institute of Technology, Bhubaneswar, Odisha, India 4(6): 103-109.

14. Nweze EL, Okafor JI \& Njokn O (2004). Antimicrobial activity of methanolic extract of (Tremaguinensis) (Schumm and Thorn) and (Morindalucida Benth) used in Nigeria. J Bio Res 2: 39-46.

15. Okeke MI, Iroegbu CU, Eze EN, Okoli AS \& Esimone CO (2011). Evaluation of extracts of the roots of Landolphiaowerrience for antibacterial activity. J Ethnopharmacol 78: 119-127.

16. Barkatullah, Ibrar M \& Muhammad N (2011). Evalution of (Zanthoxylum armautm) DC for in-vitro pharmacognostical screening. Afri $J$ Pharm Pharmacol 5(14): 1718-1723.

17. Dahham SS, Ali MN, Tabassum H \& Khan M (2010). Studies on antibacterial and antifungal activity of pomegranate (Punica granatum L.). Amer Eurasian J Agric Environ Sci 9(3): 273-28.

18. Naseemullah, Ali J, Khan FA, Khurram M, Hussain A \& Rahman IU (2012). Proximate composition, minerals content, antibacterial and antifungal activity evaluation of pomegranate (Punica granatum L.) peels powder. Middle-East J Sci Res 11(3): 396-401.
19. Nuamsetti T, Dechayuenyong $P \quad \&$ Tantipaibulvut S (2012). Antibacterial activity of pomegranate fruit peels and arils. Sci Asia 38(3): 319-322.

20. Dahham, SS, Ali MN, Tabassum H \& Khan M (2010). Studies on antibacterial and antifungal activity of pomegranate (Punica granatum L.). Am. Eurasian $J$ Agric Environ Sci 9(3), 273-28.

21. Deshpande RR, Kale AR, Ruikar AD, Panvalkar PS, Kulkarni AA, Deshpande NR \& Salvekar JP (2011). Antimicrobial Activity of different extracts of (Juglans regia $\mathrm{L}$.) against Oral Microflora. Int $J$ Pharm Sci 3:200-201.

22. Poyrazolu EC \& Biyik H (2010). Antimicrobial activity of the ethanol extracts of some plants natural growing in Aydin, Turkey. Afr J Microbiol Res 4: 2318-2323.

23. Baliga MS, Jagetia GC, Ulloor JN, Baliga MP, Venkatesh P, Reddyc R, Raoa M, Baliga BS, Devi S, Raju SK, Veeresh V, Reddya TK \& Bairy KL (2004). The evaluation of the acute toxicity and long term safety of hydroalcoholic extract of Sapthaparna (Alstonia scholaris) in mice and rats. Toxicol Letters 151: 317-326.

24. Li W, Amos K, Li M, Pu Y, Debolt S, Ragauskas JA, Shi J (2018). Fractionation and characterization of lignin streams from unique high-lignin content endocarp feeddstocks. Biotechnol for Biofuels 11(1): 1-14.

25. Moghaddam ZP, Mohammadi A, Feyzi P, Peiman (2017). In vitro antioxidant and antibacterial activity of various extract from exocarp and endocarp of walnut. Pak J of Pharma Sci 30(50). 